\title{
Training needs among maritime professionals: a cross sectional study
}

\author{
Binu Shah, Despena Andrioti, Olaf Chresten Jensen
}

Centre for Maritime Health and Society, Department of Public Health, University of Southern Denmark, Esbjerg, Denmark

\begin{abstract}
Background: Maritime medical practice includes assessment of fitness, management of medical emergencies and healthcare on board and ashore. A better response to seagoing professionals' health requirements can be achieved when all the respective stakeholders have a common understanding. Training is a powerful tool to raise awareness and in particular continuing professional development is very significant in sustaining competencies of these professionals. The objective of the study was to identify maritime professionals' perceived training needs.

Materials and methods: A cross-sectional study was conducted among maritime professionals participated in the $14^{\text {th }}$ International Symposium on Maritime Health. Fifty responses with the response rate of $42.7 \%$ were received with medical doctors representing $78 \%$ of the sample. Descriptive statistics were used to describe the basic characteristics of the data needs using STATA 15.1.

Results: Among the 23 themes, the ranking of perceived training needs was highest for fitness evaluation and examination guidelines and working conditions (both with the same percentage $86 \%$ ), onboard medicine $82 \%$, rules and regulations and health and safety at work (with the same percentage $80 \%$ ). The lowest was on gender issues $32 \%$. Conclusions: The finding suggests the planning and effective implementation of further training for the maritime health professionals in a variety of topics including financing and management issues. Highest importance of training was expressed by those over 40 years and by medical doctors with more than 10 years of practice. These findings could usefully be combined with a qualitative study to gain in-depth results and may help the respective authorities to organise relevant training.
\end{abstract}

(Int Marit Health 2018; 69, 2: 129-136)

Key words: perceived training needs, health professionals, maritime sector, symposium on maritime health

\section{INTRODUCTION}

The maritime industry is one of the most significant contributors to the process of globalisation as this sector accounts for $90 \%$ of global trade [1]. Thus, seafarers make a significant contribution to the global economy, but studies show that their health has received comparatively little attention [2]. They spend most of the their working lives at sea with limited chances to seek timely health services and so they can be considered a "hard to reach group" [3]. Maritime doctors often have to deal with medical emergencies using telecommunications and with limited on board human resources and medical equipment in challenging environments [4].
The World Health Organisation (WHO), International Labour Organisation (ILO) and International Maritime Organisation (IMO) formulated the rules and regulations regarding the competencies of medical doctors performing medical examinations for seafarers [5]. These international regulations stated that the medical healthcare on board should be as similar and as feasible with this on shore. Maritime medical practice includes the assessment of fitness, follow-up in terms of periodical medical examinations, management of medical emergencies and health care on board and ashore [6]. It also includes advice on maritime occupational medicine and working conditions on board [7]. In addition, practitioners play a significant role in performing statutory 
health assessments, communications with authorities and follow up practices on board $[8,9]$.

International Maritime Organisation stated that "shipping is perhaps the most international of all the world's great industries and one of the most dangerous" as an ocean is the most dangerous workplace on the planet regarding health and safety at work and availability of medical care [10]. Some of the other features on board like staying away (for a long period) from family, perils of the sea, weather, temperature differences, shifts culture, fatigue, piracy and psychological stress define seafaring as high-risk profession [11]. ILO estimated that in many regions, the risk of human immune virus (HIV) infection is increasing [12]. Cardiovascular diseases were reported to be one of the causes of disability and evacuation [13]. Furthermore, the mental health of seafarers is considered to be poor. Depression and suicide are significant mental health problems among them [14]. The role of health professionals is important in taking care of seafarers' health by offering comprehensive health care according to their needs, therefore relevant training is required.

The aim of this study was to explore the perceived training needs of the professionals who are employed in the maritime sector.

More specifically continuous professional development is significant in supporting the sustained competencies of health care providers. The health professions are well established with social responsibilities based on statutory regulations that require them to aim to fulfil the health expectations of the population [15]. Training is essential for seafarers too. Every 5 years, IMO recommends refresher first-aid training which should include skills such as basic cardiopulmonary resuscitation and, for some officers, medical care on board. Additional regular training on handling hazardous material exposure and chemical spillage is necessary where relevant [16]. In addition, other professionals, including managers, lawyers and insurance employees engaged in shipping industry should be familiar with working conditions on board and should have a clear understanding on seafarers' needs to perform their duties in an effective way.

\section{MATERIALS AND METHODS}

A cross-sectional study was designed to analyse and aggregate the size, distribution, and association between the maritime professional's personal characteristics and their perceived training needs. The sample population included medical doctors, nurses, researchers, administrators and other professionals participated in the $14^{\text {th }}$ International Symposium on Maritime Health (ISMH) which took place in Manila, the Philippines on 21-24 March 2017.

The questionnaire was based on international standards consisted of two sections with a total of 39 questions, two of them open-ended. It was distributed electronically to all 117 participants of the conference. The response rate was $42.7 \%$. Medical doctors represented $78 \%$ of the sample. The first section dealt with the demographic characteristics of the participants and the second referred to the perceived training needs using 23 related topics. The responses of the questionnaires were recorded in 5 points Likert scale ( 1 = very low importance... 5 = very high importance). Responses of very low, low importance and neutral were recoded into low importance. Likewise, the responses of high and very high importance were categorised into high importance. The prevalence of perceived training needs was analysed in two phases through ranking and prioritisation of training needs. For this categorisation, we used the method described by Kasvosve et al. in 2014 [17]. Competencies ranked equal or above $80 \%$ were included in priority $1,70-79 \%$ in priority $2,60-69 \%$ in priority 3 while priority 4 consisted of topics with a score of $\leq 59 \%$ [17]. Descriptive statistics were used to describe the basic characteristics of the data. The analysis was done using the STATA 15.1.

\section{RESULTS}

The sample is presented in the Table 1. Participants rated each topic according to their perceived importance as shown in Table 2. The total of 23 suggested training topics were further categorised into four domains according to similar characteristics. These domains were (i) health safety and risk management (ii) policy, rules and regulations (iii) maritime health services (iv) leadership and human resource management. Each of the four domains got an average score based on the topics included.

Health safety and risk management domain was ranked highest (mean 83\%). In this domain, working conditions $(86 \%)$ and health and safety at work (80\%) were perceived as highly important. Policy, rules and regulations was ranked as the second highest (mean 73\%). This domain included seven topics. Among them, fitness evaluation and medical examination guidelines $86 \%$, rules and regulations $84 \%$, national and international health policies and networking $72 \%$, international health regulations $70 \%$ and monitoring and health legislation implementation $70 \%$. Also, this domain included prevention programme planning (68\%), health economics and system polices (60\%).

Maritime health services ranked the third highest (mean $72.5 \%$ ). It consisted of eight sub-themes. The participants listed, onboard medicine (82\%), early diagnosis and follow up (78\%), maritime medicine emergencies (74\%), organisation of maritime services and resources (74\%), evaluation of services (72\%) and disease diagnosis, prevention and reporting (72\%) as highly important, followed by clinical registers (66\%) and electronic medical records (62\%). 
Table 1. Sample characteristics of maritime health professionals $(n=50)$

\begin{tabular}{|c|c|}
\hline Characteristics and categories & \\
\hline \multicolumn{2}{|l|}{ Age group: } \\
\hline$>40$ years & $78 \%$ \\
\hline$<40$ years & $22 \%$ \\
\hline \multicolumn{2}{|l|}{ Gender: } \\
\hline Male & $58 \%$ \\
\hline Female & $42 \%$ \\
\hline \multicolumn{2}{|l|}{ Nationality: } \\
\hline European & $42 \%$ \\
\hline Filipino & $36 \%$ \\
\hline Other & $22 \%$ \\
\hline \multicolumn{2}{|l|}{ Profession: } \\
\hline Medical doctor & $78 \%$ \\
\hline Other professionals & $22 \%$ \\
\hline \multicolumn{2}{|l|}{ Highest degree: } \\
\hline University degree & $84 \%$ \\
\hline Master in maritime medicine & $16 \%$ \\
\hline \multicolumn{2}{|l|}{ Specialisation: } \\
\hline General practice & $32 \%$ \\
\hline Occupational health & $32 \%$ \\
\hline Other & $36 \%$ \\
\hline \multicolumn{2}{|l|}{ Perform health examinations: } \\
\hline Yes & $52 \%$ \\
\hline No & $48 \%$ \\
\hline \multicolumn{2}{|l|}{ Years in practice: } \\
\hline More than 10 years & $69 \%$ \\
\hline Less than 10 years & $31 \%$ \\
\hline \multicolumn{2}{|l|}{ Preference learning environment: } \\
\hline Face to face & $60 \%$ \\
\hline E-learning & $40 \%$ \\
\hline
\end{tabular}

Leadership and human resource management was ranked fourth (mean $57.7 \%$ ). Here six topics were included. The respondents ranked multicultural health $70 \%$, tele-medical advice $66 \%$, communication skills with patients and authorities $62 \%$ and leadership and management $60 \%$ followed by research methodology (56\%) and gender issues (32\%).

The above ranked perceived training needs are presented in the Table $3 a$ and Table 3b combined with their characteristics. These demographic characteristics included age-group, gender, nationality, profession, highest degree, specialisation, performing health examinations and years of practice. Highest importance of training was expressed
Table 2. Ranking of perceived training needs $(n=50)$

\begin{tabular}{|c|c|c|}
\hline \multirow[t]{2}{*}{ Topics } & \multicolumn{2}{|l|}{ Ranking (\%) } \\
\hline & $\begin{array}{l}\text { High } \\
\text { importance }\end{array}$ & $\begin{array}{l}\text { Low } \\
\text { importance }\end{array}$ \\
\hline $\begin{array}{l}\text { Health safety and risk } \\
\text { management }\end{array}$ & $83 \%$ & \\
\hline Working conditions on board & 86 & 14 \\
\hline Health and safety at work & 80 & 20 \\
\hline Policy, rules and regulations & $73 \%$ & \\
\hline $\begin{array}{l}\text { Fitness evaluation and } \\
\text { examination guidelines }\end{array}$ & 86 & 14 \\
\hline Rules and regulations & 84 & 16 \\
\hline $\begin{array}{l}\text { National, international policies } \\
\text { and networking }\end{array}$ & 72 & 28 \\
\hline International health regulations & 70 & 30 \\
\hline $\begin{array}{l}\text { Monitoring and legislation } \\
\text { implementation }\end{array}$ & 70 & 30 \\
\hline Prevention programme planning & 68 & 32 \\
\hline $\begin{array}{l}\text { Health economics and system } \\
\text { policies }\end{array}$ & 60 & 40 \\
\hline Maritime health services & $72.5 \%$ & \\
\hline Onboard medicine & 82 & 18 \\
\hline Early diagnosis and follow up & 78 & 22 \\
\hline Maritime medicine emergencies & 74 & 26 \\
\hline $\begin{array}{l}\text { Organisation of services and } \\
\text { resources }\end{array}$ & 74 & 26 \\
\hline Evaluation of services & 72 & 28 \\
\hline $\begin{array}{l}\text { Disease diagnosis, prevention } \\
\text { and reporting }\end{array}$ & 72 & 28 \\
\hline Clinical registers & 66 & 34 \\
\hline Electronic medical records & 62 & 38 \\
\hline Leadership and HR management & $57.7 \%$ & \\
\hline Multicultural health & 70 & 30 \\
\hline Tele-medical advice & 66 & 34 \\
\hline $\begin{array}{l}\text { Communication skills with } \\
\text { patients }\end{array}$ & 62 & 38 \\
\hline Leadership and HR management & 60 & 40 \\
\hline Research methodology & 56 & 44 \\
\hline Gender issues & 32 & 68 \\
\hline
\end{tabular}

$\mathrm{HR}$ - human resources

by especially those over 40 years, those with university degree, and the medical doctors with more than 10 years of practice. The medical doctors scored higher in almost all the suggested topics with more than $72 \%$. In addition, those with more years of experience showed a clear need for training in all the suggested topics. 


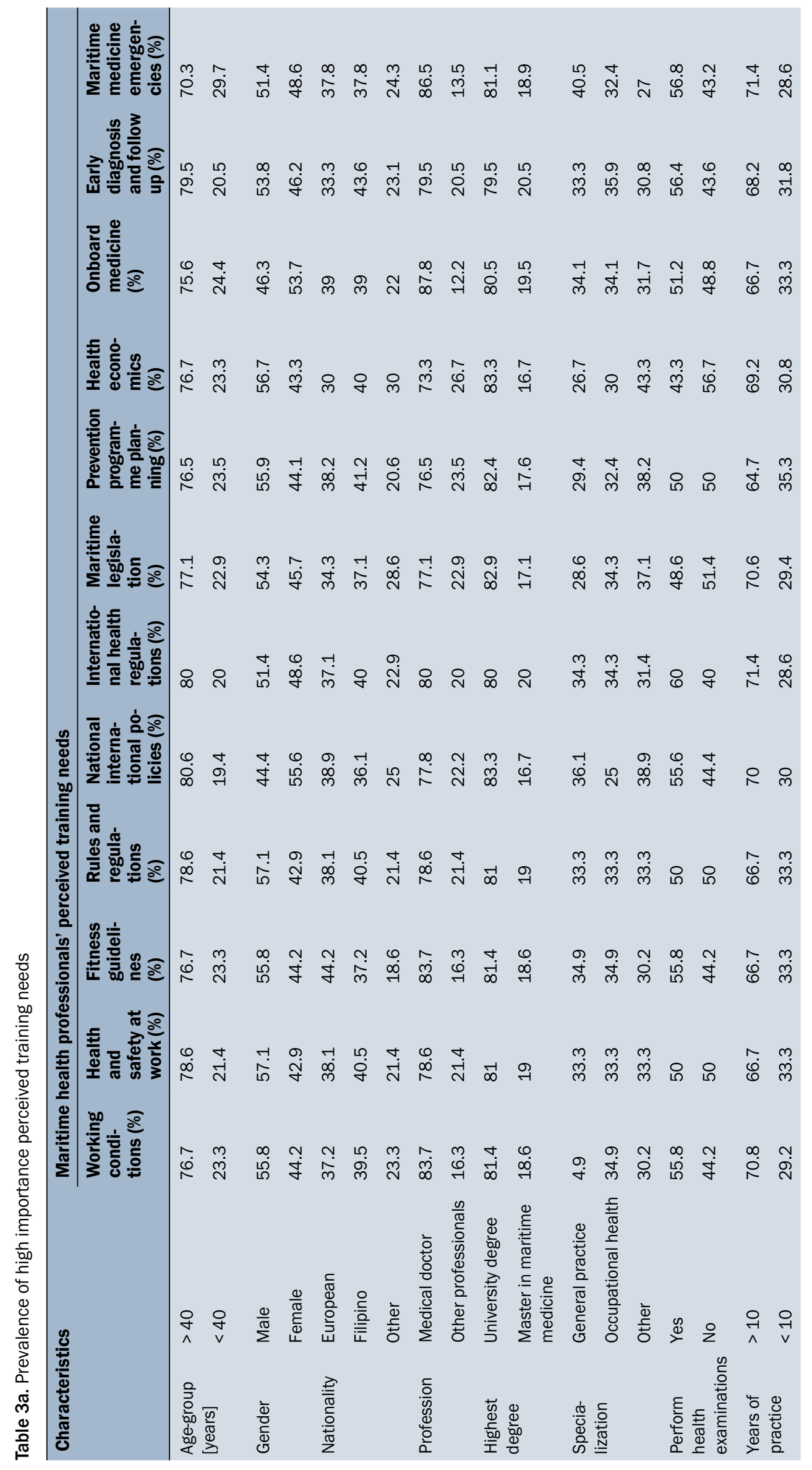




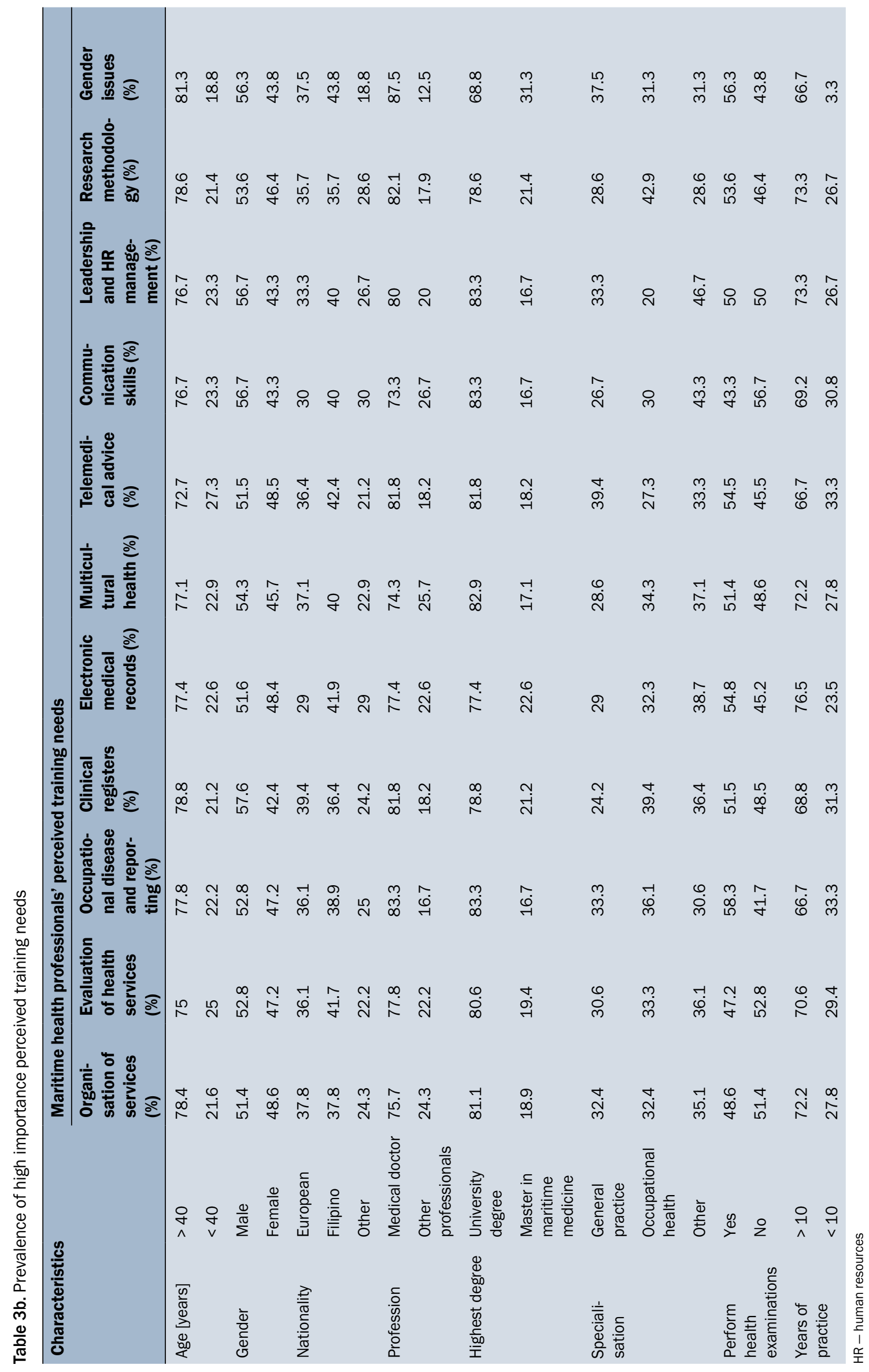


Table 4. Prioritisation of sub-themes of training needs $(n=50)^{\star}$

\begin{tabular}{|c|c|c|c|}
\hline $\begin{array}{l}\text { Priority } 1 \\
\geq 80 \%\end{array}$ & $\begin{array}{l}\text { Priority } 2 \\
70-79 \%\end{array}$ & $\begin{array}{l}\text { Priority } 3 \\
60-69 \%\end{array}$ & $\begin{array}{l}\text { Priority } 4 \\
\leq 59 \%\end{array}$ \\
\hline $\begin{array}{l}\text { Fitness evaluation and medical } \\
\text { examination guidelines }\end{array}$ & $\begin{array}{l}\text { Early diagnosis and } \\
\text { follow up }\end{array}$ & $\begin{array}{l}\text { Prevention programme } \\
\text { planning }\end{array}$ & Research methodology \\
\hline Working conditions & Maritime medicine emergencies & Clinical registers & Gender issues \\
\hline Rules and regulations & $\begin{array}{l}\text { Organisation of maritime health } \\
\text { services }\end{array}$ & Tele-medical advice & \\
\hline Onboard medicine & $\begin{array}{l}\text { National and international health } \\
\text { policies and networking }\end{array}$ & $\begin{array}{l}\text { Communication skills with } \\
\text { patients and authorities }\end{array}$ & \\
\hline \multirow[t]{4}{*}{ Health and safety at work } & Evaluation of health services & Electronic medical records & \\
\hline & $\begin{array}{l}\text { Occupational disease diagnosis, } \\
\text { prevention and reporting }\end{array}$ & $\begin{array}{l}\text { Health economics and health } \\
\text { system policies }\end{array}$ & \\
\hline & $\begin{array}{l}\text { International health regulations } \\
\text { Multicultural health }\end{array}$ & Leadership and HR management & \\
\hline & $\begin{array}{l}\text { Monitoring and health legislation } \\
\text { implementation }\end{array}$ & & \\
\hline
\end{tabular}

*Each of the 23 competencies of perceived training needs was prioritised into four domains as priority 1, priority 2 , priority 3 and priority 4 according to their scores of importance; HR - human resources

\section{PRIORITISATION OF TRAINING NEEDS}

Prioritisation of training was done in order to categorise the topics in clusters as per their perceived importance. Each of the 23 competencies of perceived training needs was prioritised into four domains as priority 1 , priority 2 , priority 3 and priority 4 according to their scores of importance. Competencies ranked equal or above $80 \%$ were included in priority $1,70-79 \%$ in priority $2,60-69 \%$ in priority 3 while priority 4 consisted of topics with a score of $\leq 59 \%$ [17]. It was not possible to consider all the four priorities with their competencies for further analyses due to the small number of responses. So, only competencies of priority 1 and priority 2 were considered in the analyses (Table 4).

\section{OPEN-ENDED QUESTIONS}

In addition, the participants expressed their major concerns and gave suggestions. As it is apparent from the answers, the open-ended questions were answered mostly by medical doctors. Their major concerns lay with the limited availability of training in maritime medicine, and the limited application of occupational standards in shipping and fishing vessels. Additional concerns were expressed on the various requests of interested parties for more detailed medical examinations and the use of personal health data for other purposes including claims.

Almost one third of medical doctors of those who answered the open-ended questions pointed out the need for formal training in maritime medicine. Epidemiology and statistics on morbidity and mortality of seagoing personnel together with evidence-based practice in maritime health and prevention, the ship medicine chest and medical emergencies at sea were highlighted as important steps to update their knowledge and stay current. Additional suggestions included the use of one global standard set of guidelines on the medical examination of seafarers by all the interested parties.

\section{DISCUSSION}

Continuous professional development is necessary for supporting sustained knowledge of professionals as education and training affect skills, ability, and competency of an individual. The performance of the employees and their required needs for education and training are determined by their professional activities' [18]. There might be different possible reasons behind the selection of the topics for training such as social desirability, familiarity and years of working experience in the maritime sector [19]. To our best knowledge, this is the first study to present the prevalence of the perceived training needs of professionals engaged in the maritime sector.

Among the four domains of competencies, the majority of the respondents perceived competencies in health safety and risk management as the most important for training (83\%) followed by topics related to policy, rules and regulations (73\%) and maritime health services (72.5\%). The competencies in leadership and human resource management were the least perceived training needs by the respondents (57.7\%). Self-assessments are more likely to be influenced by what respondents think they will achieve from professional growth and further carrier advancement perspective [20, 21]. However, this might be influenced by the small numbers of participants other than medical doctors. 
With regards to individual scoring of competencies, both working conditions on board (86\%) and fitness evaluation and medical examination guidelines (86\%) were the highest ranked training needs. Maritime health professionals should be familiar with specific risks that may arise on board like noise, vibrations, physical and chemical hazards. As occupational health and safety $(80 \%)$ is the significant component of maritime health, deep understanding in work-related challenges and injuries is also needed [6]. However, the whole shipping industry together with officers employed in the relevant national and international authorities should be familiar and have a clear understanding with seafarers' working conditions, rights, and international rules and regulations. So, targeted training should include these professionals too.

Along with the medical care services, maritime health professionals also have to perform administrative tasks like management, monitoring and supervision of food and water to ensure quality, and nutritional balance [22]. However, competencies relating to communication, organisation and management, scored lower. Only 6 out of 10 respondents prioritise training on leadership and management. The reason might be that most of the participants were medical doctors $(78 \%)$ and not particularly interested on these topics.

Furthermore, research methodology (56\%) and gender issues (32\%) were not considered important topics by the respondents, with similar percentages between genders. It can be assumed that both male and female participants had an equal opportunity of exposures and did not consider gender issue as high important. However, it should be noted that gender-related discrimination, ranging from distorted expectations of work capacity to sexual harassment were some of the issues reported by the women seafarers [23], suggesting maritime health professionals to be aware on gender issues to be better prepare for respond to this.

Regarding participation in courses about maritime medical issues, studies showed that maritime doctors with more than 10 years of practice, performing more than 20 annual pre-employment examinations are more interested in training [24, 25]. Similar findings summarised that with the increase in age and thus experience, the level of knowledge and skills also increases but there might be a more pressing need for theoretical knowledge to stay current [26, 27].

The open-ended questions were answered mainly by medical doctors, as is apparent by the answers, who expressed their concerns about among others, the requests for a variety of pre-employment medical tests, the use of personal health data for other purposes including claims, the little attention to occupational needs of seagoing personnel, and the limited availability of training in maritime and diving medicine.

In line with this they pointed out the need for establishing an "official" training programme in maritime and diving medicine, preferably face-to-face, to gain knowledge in epidemiology, statistics, evidence-based prevention and medical practice. Furthermore, they highlighted the need for a single set of global guidelines for the medical examinations of seafarers as well as the need for guiding principles for personal data protections.

\section{LIMITATIONS OF THE STUDY}

This study subjects to some limitations such as in occupational settings, population-based surveys might be affected by low response rate that can bias prevalence estimations. In the current study, the response rate was $42.7 \%$ which is typical for the sector but makes it hard to generalise to all the professionals of the maritime sector. Likewise, participants' self-reports are vulnerable to overestimation and measurement bias. A study in larger sampling population might give more representing results. Additional uses of a mixed methods approach including in-depth interviews and focus groups would have more detailed information on training perceptions. Never the less this study, is a first attempt to show maritime professionals perceptions related to their training globally.

\section{CONCLUSIONS AND RECOMMENDATIONS}

The study should be repeated in the upcoming international maritime health symposia but can also be applied in other kinds of conferences. This sort of research needs to be extended to different maritime settings internationally. To study the expressed needs in detail for training, qualitative studies might be combined with quantitative ones. The former could be done among the group of maritime doctors and representatives from ship owners, unions, and the maritime authorities. Based on this, training courses about the priority issues for the professionals serving the shipping industry could be established. Similarly, longitudinal studies would be relevant to examine the consistency of training perception and its predictors. University degree graduates, participants over 40 years old and with more than 10 years of practice self-identified a greater need for training. Medical doctors scored higher in all the suggested topics.

\section{ACKNOWLEDGEMENTS}

We are grateful to all the participants in the survey. Furthermore, we would like to thank Prof. Maria Rosa Fenoll Brunet MD, PhD, Universitat Rovira i Virgili, Spain and Dr. Luisa Canals, IMHA-Research for their precious contributions to several revisions of the questionnaire.

\section{REFERENCES}

1. Li Z, Xu M, Shi Y. Centrality in global shipping network basing on worldwide shipping areas. GeoJournal. 2014; 80(1): 47-60, doi: 10.1007/s10708-014-9524-3.

2. Zhang $P$, Zhao M. Maritime health of Chinese seafarers. Marine Policy. 2017; 83: 259-267, doi: 10.1016/j.marpol.2017.06.028. 
3. Poulsen TR, Burr H, Hansen HL, et al. Health of Danish seafarers and fishermen 1970-2010: What have register-based studies found? Scand J Public Health. 2014; 42(6): 534-545, doi: 10.1177/1403494814534538, indexed in Pubmed: 4876236.

4. Dahl E. Cruise ship's doctors - company employees or independent contractors? Int Marit Health. 2016; 67(3): 153-158, doi: 10.5603/ IMH.2016.0028, indexed in Pubmed: 27681214.

5. Heikki Saarni. Medical examinations of seafarers and training for medical doctors in maritime health. Actual Problems of Transport Medicine. 2005.

6. Norwegian Centre for Maritime Medicine. Textbook of Maritime Medicine, Norway. 2014.

7. International Maritime Organization. International Convention on Standards of Training, Certification and Watchkeeping for Seafarers, 1978, as amended in 1995 and. 1997; 1995: 255.

8. The Organization for Economic Co-operation and Development. Value for money in health services, Paris: OECD. 2010.

9. World Health Organization. Health literacy the solid facts. WHO Regional Office for Europe. 2013.

10. International Maritime Organization. International safety management code: ISM code and revised guidelines on the implementation of the ISM code by administrations. International Maritime Organization. London. 2002: 39.

11. Mitroussi K, Notteboom T. Getting the work done: motivation needs and processes for seafarers and dock workers. WMU Journal of Maritime Affairs. 2014; 14(2): 247-265, doi: 10.1007/s13437014-0064-y.

12. Chowdhury SAA, Smith J, Trowsdale S, et al. HIV/AIDS, health and wellbeing study among International Transport Workers' Federation (ITF) seafarer affiliates. Int Marit Health. 2016; 67(1): 42-50, doi: 10.5603/IMH.2016.0009, indexed in Pubmed: 27029929.

13. Levenson JW, Skerrett PJ, Gaziano JM. Reducing the global burden of cardiovascular disease: the role of risk factors. Prev Cardiol. 2002; 5(4): 188-199, indexed in Pubmed: 12417828.

14. Iversen RTB. The mental health of seafarers. Int Marit Health. 2012; 63(2): 78-89, indexed in Pubmed: 22972547.

15. Cruess RL, Cruess SR. Expectations and obligations: professionalism and medicine's social contract with society. Perspect Biol Med. 2008; 51(4): 579-598, doi: 10.1353/pbm.0.0045, indexed in Pubmed: 18997360.
16. Hansen HL, Pedersen G. Poisoning at sea: injuries caused by chemicals aboard Danish merchant ships 1988-1996. J Toxicol Clin Toxicol. 2001; 39(1): 21-26, indexed in Pubmed: 11327222.

17. Kasvosve I, Ledikwe JH, Phumaphi O, et al. Continuing professional development training needs of medical laboratory personnel in Botswana. Hum Resour Health. 2014; 12: 46, doi: 10.1186/14784491-12-46, indexed in Pubmed: 25134431.

18. Amponsah-Tawaih K, Adu MA. Work Pressure and Safety Behaviors among Health Workers in Ghana: The Moderating Role of Management Commitment to Safety. Saf Health Work. 2016; 7(4): 340-346, doi: 10.1016/j.shaw.2016.05.001, indexed in Pubmed: 27924238.

19. Epstein RM, Hundert EM. Defining and assessing professional competence. JAMA. 2002; 287(2): 226-235, indexed in Pubmed: 11779266.

20. Colthart I, Bagnall G, Evans A, et al. The effectiveness of self-assessment on the identification of learner needs, learner activity, and impact on clinical practice: BEME Guide no. 10. Med Teach. 2008; 30(2): 124-145, doi: 10.1080/01421590701881699, indexed in Pubmed: 18464136.

21. Eva KW, Regehr G. Self-assessment in the health professions: a reformulation and research agenda. Acad Med. 2005; 80(10 Suppl): S46-S54, indexed in Pubmed: 16199457.

22. Sargos $P$. Responsabilité des médecins, aléa thérapeutique et obligation de sécurité de résultat. Cahiers de stomatologie et de chirurgie. 2001(2): 7-9.

23. Alagbe J. Female seafarers' shocking revelation: To our bosses, we are just sex tools 2016. http://punchng.com/female-seafarers-shocking-revelation-bosses-just-sex-tools/.

24. Andrioti D, Faurby MD, Videbeak Le J, Jensen O. Do Danish Maritime Doctors Value Continuous Education Initiatives? Health Econ Outcome Res Open Access. 2017; 03(03), doi: 10.4172/2471-268x/1000137.

25. Jensen OC, Charalambous G. Andrioti D, Analysis of maritime doctors and general practitioners perceived training needs. Submitted Int Maritime Health. 2018.

26. Oldenburg M, Rieger J, Sevenich C, et al. Nautical officers at sea: emergency experience and need for medical training. J Occup Med Toxicol. 2014; 9: 19, doi: 10.1186/1745-6673-9-19, indexed in Pubmed: 24817903.

27. Lammintakanen J, Kivinen T. Continuing professional development in nursing: does age matter? J Workplace Learning. 2012; 24(1): 34-47, doi:10.1108/13665621211191096. 